\title{
Acute development of a paradoxical pulse in a child
}

\author{
R Leskovac ${ }^{1 *}$, D Belina ${ }^{1}$, D Anic ${ }^{1}$, Z Kovac ${ }^{2}$ \\ From 23rd World Congress of the World Society of Cardio-Thoracic Surgeons \\ Split, Croatia. 12-15 September 2013
}

\section{Background}

Paradoxical pulse is defined as a decrease of systolic blood pressure for more than $10 \mathrm{mmHg}$ during inspiration. In this presentation we would like to show the abrupt development of paradoxical pulse observable by direct intra-arterial blood pressure measurement.

Acute development of a paradoxical pulse is important in recognizing tamponade development primarily due to acute bleeding. This can lead to acute cardiogenic shock and resuscitation.

A four month old infant underwentsurgery for Tetralogy of Fallot. Postoperative course was uneventful. On the second postoperative day mediastinal and pleural tubes were removed together with atrial and ventricular electrodes. Several seconds after removal, a normal and regular intra-arterial pressure wave on the monitor became highly distorted and irregular with abnormal pulse wave and the presence of tachycardia and hypotension. Bedside transthoracic echocardiogram (TTE) showed a $10 \mathrm{~mm}$ wide pericardial effusion.

Urgent resternotomy was done in the operating room andthe vast amount of coagulum with dark venous blood was found in the pericardium. Active bleeding of the right atrium auricula was verified at the site where a temporary unipolar electrostimulation electrode was previously positioned. The infant was extubated the same night and discharged from the hospital on the fourteenth day.

\section{Conclusion}

Sudden presentation of 'unexpected irregularpulse' implied presence of acute pericardial tamponade that was a result of right atrial haemorrhage. Recognizing the

\footnotetext{
* Correspondence: reneleskovac@gmail.com

'Department of Paediatric Cardiac Surgery, Zagreb University Hospital,

Zagreb, Croatia

Full list of author information is available at the end of the article
}

paradoxical pulse in the ICU setting is important in order to avoidmorbidity in paediatric surgical patients.

\section{Authors' details}

'Department of Paediatric Cardiac Surgery, Zagreb University Hospital, Zagreb, Croatia. ${ }^{2}$ Department of Pathophysiology, Zagreb University Hospital, Zagreb, Croatia.

Published: 11 September 2013

doi:10.1186/1749-8090-8-S1-0314

Cite this article as: Leskovac et al: Acute development of a paradoxical pulse in a child. Journal of Cardiothoracic Surgery 2013 8(Suppl 1):O314.

Submit your next manuscript to BioMed Central and take full advantage of:

- Convenient online submission

- Thorough peer review

- No space constraints or color figure charges

- Immediate publication on acceptance

- Inclusion in PubMed, CAS, Scopus and Google Scholar

- Research which is freely available for redistribution

Submit your manuscript at www.biomedcentral.com/submit
() Biomed Central
C Biomed Central

(c) 2013 Leskovac et al; licensee BioMed Central Ltd. This is an Open Access article distributed under the terms of the Creative Commons Attribution License (http://creativecommons.org/licenses/by/2.0), which permits unrestricted use, distribution, and reproduction in any medium, provided the original work is properly cited. 